IZA DP No. 6079

Studying the NAIRU and its Implications

Vasiliki Bozani

Nick Drydakis

October 2011

Forschungsinstitut zur Zukunft der Arbeit Institute for the Study of Labor 


\title{
Studying the NAIRU and its Implications
}

\author{
Vasiliki Bozani \\ University of Crete \\ Nick Drydakis \\ University of Patras \\ and IZA
}

\section{Discussion Paper No. 6079 \\ October 2011}

\author{
IZA \\ P.O. Box 7240 \\ 53072 Bonn \\ Germany \\ Phone: +49-228-3894-0 \\ Fax: +49-228-3894-180 \\ E-mail: iza@iza.org
}

\begin{abstract}
Any opinions expressed here are those of the author(s) and not those of IZA. Research published in this series may include views on policy, but the institute itself takes no institutional policy positions.

The Institute for the Study of Labor (IZA) in Bonn is a local and virtual international research center and a place of communication between science, politics and business. IZA is an independent nonprofit organization supported by Deutsche Post Foundation. The center is associated with the University of Bonn and offers a stimulating research environment through its international network, workshops and conferences, data service, project support, research visits and doctoral program. IZA engages in (i) original and internationally competitive research in all fields of labor economics, (ii) development of policy concepts, and (iii) dissemination of research results and concepts to the interested public.
\end{abstract}

IZA Discussion Papers often represent preliminary work and are circulated to encourage discussion. Citation of such a paper should account for its provisional character. A revised version may be available directly from the author. 


\section{ABSTRACT}

\section{Studying the NAIRU and its Implications}

The current paper is a means of demonstrating our knowledge about macroeconomic theories, and its key variables, phenomena, and history. Given the key role that the NonAccelerating Inflation Rate of Unemployment (NAIRU) has in the macroeconomic theory as well as its role in determining employment theories, it is raised the need for a thorough evaluation of its origins and a brief explanation of some of the claims surrounding it. In these grounds, this study aims at integrating and generalizing findings and presenting the changes within the macroeconomic field over the years by investigating theories, identifying methodological strengths and the weaknesses in the body of the macroeconomic research about the concept of NAIRU. In order to help the reader to avoid misunderstandings we define the best descriptors and identify the best sources to use in the review literature related to our topic, we rely on primary sources in reviewing the literature, we examine critically all aspects of the research design and analysis, and we consider contrary findings and alternative interpretations in synthesizing quantitative literature.

JEL Classification: E02, E24, E61

Keywords: NAIRU, macroeconomic policies

Corresponding author:

Vasiliki Bozani

Department of Economics

University of Crete

Gallous Campus

Rethymno, 74100

Greece

E-mail: bozanivaso@gmail.com 


\section{Introduction}

Considering the use of the Non-Accelerating Inflation Rate of Unemployment (NAIRU hereafter) as the reference point for macroeconomic policies, the goal of this study is to demonstrate our knowledge about macroeconomic theories. The setting of NAIRU at the center of policy decisions is not to be questioned since it reflects perfectly the simplified mechanism of the relation between unemployment and inflation by determining the long-run equilibrium level of unemployment at which there is neither upward nor downward inflation pressures; hence in the presence of any unemployment level below the predetermined NAIRU level itself should be followed by inflation reductions and vice versa. In these grounds, with respect to the consistency of new Keynesian NAIRU concept with supply side economics, any attempt to face a possible unemployment gap (except for the case where actual unemployment is close to NAIRU) is coincided with changes in labor market. Further the treatment of the variable of unemployment as a structural factor allows its actual levels to be fluctuated around its long-run equilibrium.

Despite the significance of this concept in shaping the broader macroeconomic conditions in the sense that its consistency with inflation targeting expands economic activity, its theoretical background and implications are usually ignored. As a result, the main purpose of this study is to research the macroeconomic theories, gain deeper understanding through their insights and contribute to publicly available macroeconomic knowledge of theory and policy. Alternatively, we aim at informing individuals about changes in the macroeconomic fields so as to supplement their lacks at theoretical grounds and reveal the insufficiency of the current theories so as to justify that other theories should be put forth. Our scope is to inform individuals of the influential researchers and research groups in the macroeconomic field. This study is structured to integrate reviews and present the reader with the big picture. Besides without integration, the map of the research landscape would be as large as the research landscape itself.

Apart from proof of knowledge and the identification of a research family, the reasons of this study is to delimiting the research problem, to seek alternative lines of theory, to gain methodological insights, to identify recommendations for further research and policy. The organizational scheme is built around the above concepts and is organized in accordance with the various theories in the literature. More 
specifically, Section 2 focuses on the Phillips curve and its rearrangements, since the Phillips curve is the key element about the relation between inflation and unemployment, until the introduction of NAIRU in macroeconomic theory. Although, for many economists the concept of the NAIRU is a useful piece of business cycle theory, for a number of economists the NAIRU concept is being of a limited use for predicting inflation, understanding its causes and therefore making employment policies. In a sequence Section 3 evaluates the relation that stands between NAIRU and unemployment, while Section 4 signals out the questions that arise about the appropriateness and the correctness of NAIRU concept for setting employment policies. The last section of this study concludes that attention should be paid on the real macroeconomic magnitudes in order economic growth to be achieved.

\section{The theoretical framework of NAIRU}

Among to the developments that have taken place in macroeconomic grounds the most significant concerns the replacement of the orthodox Keynesian Phillips curve, as a framework to examine unemployment, with the supply side framework of NAIRU. Although the development of NAIRU signifies changes in both theoretical and policy grounds, contemporary macroeconomic analysis rarely focuses on its theoretical framework and its implications, which to a great extent determine their realism and applicability in the analysis of real world economies. Considering all these, we examine the process of Phillips curve form and implications until its connection with the NAIRU concept.

\section{I. The orthodox Keynesian Phillips curve: the basis for macroeconomic evaluation}

Regarding the development of Keynesian economics and the introduction of "General Theory" (Keynes, 1936) as the starting point in this study, we intent to examine the developments that took place until the introduction of NAIRU in economic theory. The choice of this point is explained by the fact that at its centre is set the problem of unemployment, which was the main characteristic of economies during the Great Depression. Besides, Keynes's attempts to provide adequate solutions for unemployment changed the whole economic thought. In Keynesian grounds the dominated assumption about the presence of the positive relation between unemployment and wage gap was rejected, while aggregate demand was recognized to be essential about the behavior of economic activity in general. In these conditions, 
unemployment was characterized as involuntary; it could be presented even at the equilibrium level and could be faced by concentrating on demand (fiscal) management policies (Snowdon and Vane, 2005; Mankiw, 1990)1. In other words, a Keynesian type economic expansion is related with the adoption of policies that provide adequate ways so that aggregate demand to be shifted upward and fuel economic activity (Romer, 1993; Mankiw, 1990).

In particular the Keynesian approach is believed to be reflected on the IS-LM model which defines the intersection between product and money markets as the necessary condition for determining equilibrium levels of interest and income rates consistent with both of these markets and the assumptions about wage and price stickiness $^{2}$. In this manner, money wages and interest rate rigidities cause under unemployment levels in terms of IS-LM. Furthermore, under the assumption about consistency of fixed money wage and price levels with their money market equilibrium, unemployment is attributed to excess labor supply without the equilibrium price affecting money wages (Snowdon and Vane, 2005; Solow, 1979).

Despite the importance of the Keynesian IS-LM system, the absence of any reference to price level led to its characterization as incomplete; such incompleteness was filled with the development of the Phillips curve that introduced the variable of wage (and later price) inflation rates and provided supporting empirical evidence on Keynes's beliefs about the downward stickiness of nominal wage rates. Phillips (1958) by using data about the British economy during the period $1861-1957^{3}$, examined the hypothesis of whether rates of changes in money wages could be explained through unemployment levels or the rate of its changes ${ }^{4}$. The fundamental characteristic of the

${ }^{1}$ Although in Keynesian grounds only demand policies can cause permanent price stability and full employment conditions, the adoption of other policies or their combination with fiscal policies is not rejected as long as they aim at economic expansion (Snowdon and Vane, 2005; Mankiw, 1990).

2The determination of equilibrium through the IS-LM system is affected by the factors that determine the slope and the elasticity of each curve (respectively to whether economies are closed or open). The significance of the slopes of IS-LM curves is reflected on the fact that their responsiveness to fiscal and monetary policies determines the final impacts from the adopted policies on economic activity (Snowdon and Vane, 2005; Romer, 1993).

${ }^{3}$ Although Phillips (1958) is regarded as the generator of Phillips curve, it is believed that Irving Fischer (1926) initially provided evidences about an inverse relation between prices and employment by using data for the American economy during the period 1915-1925.

4It should be mentioned that the adopted time period for empirical investigation did 
adopted sample period was the association of low unemployment rates with rapid wage increases and respectively in cases of high unemployment rates. But the specific characteristics of each of the distinguished sub-periods and mainly by changes in import prices on retail prices and thus on the cost of living of workers in terms of real wages, are regarded as having significantly affected the provided results. In any case the strength of unemployment rate in relation to wage changes seemed to depend on the unemployment rate itself.

Generally, the Keynesian Phillips curve implies an inverse but non-linear relation between the rates of changes of money wages (growth level of money wages) and unemployment levels (rates of changes of unemployment level). Both the structure and the direction of this relation are determined by the intersection between demand and supply for labor and thereby the actual levels of employment and unemployment. Thus, when labor demand exceeds its supply there are increases in money wages that in turn raise firms' willingness to hire more employees, given the higher level of nominal and thereby lower real wages. It is therefore suggested a distinction between demand and supply for labor, which determines the power of employers and employees in labor market (Phillips, 1958).

Indeed, according to Phillips curve implications the specific characteristics of each period used for estimation as well as the dependence of unemployment relative to wage changes on unemployment rate itself can be suggested (Phillips, 1958). In accordance with the above, the Phillips curve equation:

(1) $\dot{W}=-0.9+9.638(U)^{-1.394}$

where, $\dot{W}:$ the variables of changes in the wage rates

$U:$ the variable of unemployment rate

It should be mentioned that the significance of Phillips curve implications in time is proved by the compatibility of results that cover the period during 1948-1957 with those of the early period of 1816-1913. However, the well fitted data and Phillips curve

not include the years that were in the wake of periods of rapid rise in import prices and their consequences on the cost of living. Moreover, the introduction of the variable of cost living allowed Phillips (1958) to reach an inverse relation between levels of unemployment and inflation rates, though the use of this variable is believed to contribute a close relation between its levels and the behavior of money wages (Espinosa-Vega and Russell, 1997). 
outcomes were those that forced many Keynesians to consider the possibility, in both theoretical and empirical grounds, for long-run stability of the relation between changes in wage rates or changes in wage inflation and unemployment levels; a thought that implied the presence of a stable long-run relation between unemployment and wage inflation on relatively low levels (Espinosa-Vega and Russell, 1997; Snowdon and Vane, 2005). As a result, the co-existence of a stable long-run Phillips curve and the Keynesian IS-LM system suggested that price stability would arise in cases where economies lay at levels below full employment so that real income and employment would be affected by shifts in aggregate demand. Such suggestion though, turns to be inappropriate for cases where economies are found at levels above their full employment in the sense that fixed money wages could not respond to aggregate demand shifts. As a consequences, it was implied a relation between the Keynesian theory of output and employment with a theory of wage (and later price) inflation (Dixon, 1995).

Although the assumed long-run stability of downward Phillips curve "allowed" policymakers to control both inflation and unemployment levels via "aggressive" demand management policies and governmental intervention, its adoption raised a number of questions about the labor market characteristics that had affected Phillips' estimations (Espinosa-Vega and Russell, 1997). These questions were enriched by Phillips curve's inability to reflect conditions of other economies, apart from the British economy (see Friedman, 1968). According to Samuelson and Solow (1960) however such inability resulted from the different institutional and structural characteristics, included variables and transmission mechanisms of each of these economies. Additionally, the fact that Phillips curve estimations included nominal, instead of real, wages in the sense that workers determine their decisions between working and leisure with respect to the former, raised additional doubts about Keynesian Phillips curve's appropriateness (Friedman, 1968). The fact that Phillips' (1958) beliefs about the determination of the power and social position of each worker as well as the determination of labor costs and thereby firms' labor demand through demand and not real wages were in accordance with Keynesian theory, explains satisfactorily the choice of nominal wages. Besides, in Keynesian theory the 
determination of money wages is assumed to be affected by labor and not by product market conditions (Snowdon and Vane, 2005; Romer, 1993) ${ }^{5}$.

Another relative question concerns the preference on the use of money wage instead of price inflation in the determination of Phillips curve relation (Friedman, 1968). The dilemma between these two forms of inflation is explained by the concentration of Keynesian economics on aggregate demand mainly and secondly on the supply side, without distinguishing the costs that arise from each side. Besides, Lipsey (1960) declares that the variable of inflation in Phillips curve does not include any supply side elements, while Samuelson and Solow (1960) distinguish between the cost push and the demand pull inflation according to which it is set the independency of the effects on wage and price levels on whether economy lies on its full employment level or below it 6 . Nevertheless, Samuelson and Solow's (1960) distinction was the reason for redefining the Phillips curve relation in terms of unemployment and price inflation rates.

The co-existence of these questions about Phillips curve's assumptions and the inability of long-run stable Phillips curve in facing stagnation conditions and reflecting the dynamic form of economy, provided evidences against the use of Phillips curve for stabilizing economy. As a consequence, the abandonment of Keynesian thought and the tendency to use monetary policies during 1970s came up.

\section{II. Phillips Curve and microeconomic foundations}

Given the inappropriateness of the purely Keynesian Phillips curve in reflecting the actual economic conditions due to the assumption about anticipated inflation (zero

5The concentration of classical and new classical economics on real wages rests upon the assumption that the negotiations about the determination of employment levels between employees and employers are made in terms of real wages. As a result, an inverse relation between real wages and unemployment as well as between fully flexible wages and prices is considered; assumptions that are opposed to Phillips curve assumption about price rigidity (Friedman, 1977).

'Given policymakers' inability in distinguishing inflation sources and thereby explaining satisfactorily the behavior of each of the effects with respect to time that are being examined in conjunction with the inappropriate explanation about the way that inflation should be treated, Samuelson and Solow (1960) distinguished between demand (demand pull) and supply side (cost push) inflation. The importance of distinguishing between demand pull and cost push inflation, proves the overcoming of problems such as the presence of a specific standard from which the price level can be measured or the presence of identification problem that characterises data or even more the independency in a closed economy among the markets. 
inflationary expectations) its rearrangement was required. The relatively high cost in terms of inflation that was needed for unemployment to be settled down as well as the harmful constraints that were imposed against economic expansion because of the assumed Phillips curve stability, even in the long-run, made such rearrangement necessity (Phelps, 1967, 1968). In order a more dynamic form of economies to be captured, Phillip's curve was thereby enriched with the introduction of microeconomic foundations $^{7}$ (Phelps, 1967, 1968; Friedman, 1968).

According to these changes, a downward sloping Phillips curve would lie on a specific unemployment level on the horizontal axis of unemployment at which the equality between expected and actual inflation was ensured so as the former to be unchanged. As a result, when actual unemployment rate was below its equilibrium level, inflation would be accelerated and thereby further employment expansions would take place and adequately for the other side of the inequality. In this case, the implied relation between unemployment levels and inflation rates sets the behavior of the former a good approximation for the behavior of wages (Phelps, 1967, 1968). The rearrangement of Phillips curve into monetarism grounds was completed with the determination of long-run equilibrium level of unemployment, which according to Friedman (1968) would result from the intersection of the vertical, due to the fulfillment of expectations, long-run Phillips curve with the horizontal axis of unemployment. This long-run equilibrium level of unemployment is well known as the "natural rate of unemployment", according to which: "it would be ground out by the Walrasian system of general equilibrium equations, provided there is imbedded in them the actual structural characteristics of the labor and commodity markets, including market imperfections, stochastic variability in demands and supplies, the cost of gathering information about job vacancies and labor availabilities, the cost of mobility and so on", (Friedman, 1968, p. 8).

The definition of the natural unemployment rate suggests, in accordance with the Wicksellian definition of the natural interest rate $^{8}$, that any decision to keep

7These concern the introduction of unanticipated and unexpected inflation rate, the use of inflation and unemployment steady state paths, the constraints against capacity utilization and investment levels as well as the mechanisms for price behavior for equilibrium to be determined.

8 According to Wicksellian approach the natural interest rate, which depends on the actual inflation level, is defined as the distinction between its market and natural levels. Besides, when interest rate rests on its natural level, the equality of interest 
unemployment below its natural levels is consistent with the adoption of inflationary policies (Friedman, 1968). Furthermore, the dependence of the "natural unemployment rate" on specific characteristics, rigidities and imperfections of labor and commodity markets in conjunction with the introduction of price and wage expectations, indicates the absence of any constraint against the constancy of natural rate, since it is assumed to be affected by real factors.

According to Friedman' (1968) and Phelps' (1967, 1968) implications, the augmented adaptive-expectational Phillips curve equation is therefore defined as:

(2) $\dot{W}=f(U)+\beta \dot{P}^{e}$

where, $\dot{W}:$ the rate of money wages

$f(U)$ : a component determined by the state of excess demand and simply a proxy for the level of unemployment

$\dot{P}^{e}:$ the expected rate of inflation

that requires $\beta=1$, so that no trade-off to characterise the long-run. For the case where $0 \prec \beta \prec 1$, the presence of a long-run trade-off that is less favorable compared to short-run, is implied, whereas for estimations where $\beta=0$ the Keynesian suggestion for a stable trade-off is ensured.

Friedman (1977) summarizes all these implications about the enhancement of Phillips curve with microeconomic foundations into a relation between real wages and unexpected inflation. However, the introduction of expected inflation as the variable that determines excess demand, suggests the presence of a "family" of Phillips curves that are determined relative to the expected inflation and its consequences on the other two variables. This is attributed to the fact that individuals and policymakers form their expectations and behavior, after the choice of optimal Phillips curve with respect to actual conditions (Phelps, 1967). Besides, in the face of unanticipated inflationary expansions the Phillips curve is shifted to new equilibrium points that stand until individuals adjust their behavior and expectations to these conditions ${ }^{9}$.

rate in capital markets with the return on physical capital as well as the equality between actual and natural unemployment rate is implied (Snowdon and Vane, 2005). ${ }^{9} \mathrm{As}$ a result, workers do not suffer from complete money illusion, which duration), is determined by the persistence of unanticipated inflation (Friedman, 1968). 
Hence, as long as equilibrium comes up at the time when individuals become aware of them and respond to these changes, only temporarily can monetary authorities achieve their targets.

In particular, once actual inflation is fully anticipated in the long-run, there is no trade-off between inflation and unemployment, while in the absence of excess demand any shift in money wage, mainly upward, equals to the level of expected inflation rate. So, there is no long-run stable trade-off between inflation and unemployment because of the distinction between the short and long-run effects of unanticipated changes in nominal aggregate demand. Besides, the existence of a vertical Phillips curve requires money neutrality, whereas the procedure behind the possibility of reducing unemployment below its natural unemployment rate is defined as "accelerationist hypothesis"10.

The introduction of microeconomic foundations in Phillips curve was followed by a number of difficulties in making policy decisions; in Lucas' (1975) view the solution in these difficulties could be reached only by distinguishing between real and money economy. It was therefore preferred the combination of rational expectations with the natural unemployment rate within a Walrasian framework, where in continuous market clearing and fully flexible price and wages prevail. Besides, according to Lucas (1975) the impact of Keynesian business circle approach on equilibrium is determined by considering GDP fluctuations as a disequilibrium phenomenon due to market rigidities. In addition, Lucas regards the possibility for a positive serial correlation between movements of trend and actual output level, which cannot be explained through changes in the production function during the business circle. All these, let him (Lucas) to claim that only unanticipated changes in money supply, which in turn lead to unanticipated demand shocks, could be defined as competitive equilibria that affect the economic system and cause errors in rational expectations about prices. Clearly, the combination of unanticipated shocks and incorrect expectations, due to incomplete information, is considered to be responsible for the distinction between actual employment and output levels from their long-run equilibrium (natural) levels.

\footnotetext{
${ }^{10}$ According to accelerating hypothesis any attempt to push unemployment below its natural level is tide with permanent inflation acceleration that is possible to cause hyperinflation; respectively for cases where unemployment is above its natural rate (Phelps, 1967).
} 
Hence, in Lucas' (1973) view the introduction of the natural output rate implied the dependence of the distinction between actual and natural output level on the deviation between actual and inflation rate. Also the introduction of Okun's Law (see Okun, 1962) that suggests a stable inverse relation between unemployment and GDP allowed him (Lucas) for redefining the equation of aggregate supply and expressing unemployment relative to surprise price change. As a consequence, the rationalexpectations augmented Phillips curve equation is written as:

(3) $U_{t}=U_{N_{t}}-1 / \phi\left[\dot{P}_{t}-E\left(\dot{P}_{t} / \Omega_{t-1}\right)\right], \phi \succ 0$

where, $U_{t}:$ actual unemployment rate

$U_{N}:$ natural unemployment rate

$E\left(\dot{P}_{t} / \Omega_{t-1}\right)$ :rational expected inflation that is based on the available information set from preceding period.

$\dot{P}_{t}^{e}$ : expected inflation rate

Equation (3) signals the consistency of rational expectations with a temporary reduction of unemployment below its natural level that results only from 'unanticipated' or surprise inflation changes ${ }^{11}$. The coexistence of real and nominal variables in this equation breaks down the classical dichotomy between these variables as long as the presence of rational expectations in Phillips curve allows only for unanticipated changes of money growth. Further, the relation between unemployment levels and inflation rates stands in the absence of any form of " money illusion" as long as markets are cleared and agents are allowed to form their expectations optimally (Lucas, 1972, 1973, 1975).

Nevertheless, the adoption of new classical view and its implications about natural unemployment rate implies the appropriate response of nominal interest rate to unexpected inflation shocks. Thus when inflation changes are once and for all, longrun interest rate remains unchanged since in the short-run interest rates level falls and causes output increases; a case that does not refer to the vertical Phillips curve for

11The randomly and unpredictability of the short-run trade-off is explained by the fact that the serially correlation of predictable and unpredictable components of unemployment with the unpredictable part of the error term, is explained by indirectly observed variables (Lucas, 1972; Sargent, 1972). 
which any unexpected inflation shift (usually upward) does instantaneously affect the nominal interest rate (Sargent, 1972; Sargent et al., 1973). Besides, only in the presence of fixed interest rate changes real economic magnitudes can affect the behavior of Phillips curve (Sargent, 1972; Sargent et al., 1973). In other words, the final outcome of rational-augmented Phillips curve depends on the form of expectations and the size of interest rates elasticities, while the natural unemployment rate can be shifted only by random disturbances.

Despite the differences that are raised between Friedman-Phelps' and Lucas' approaches about the factors that prevent the achievement of equilibrium levels, in both of these approaches Phillips curve's verticality determines the natural unemployment rate. As for their differences, these refer basically on the way that each of the unemployment and inflation variables are being treated in making policy decisions. For instance, for both monetarism and new classical school the possibility workers' price expectations to be fooled by inflation surprises that is consistent with the presence of persistent prices increases, stems from the treatment of inflation as a purely monetary phenomenon. In these conditions, unemployment can be reduced when the curve of workers' labor supply is located to the right of its non-surprises position. On the other side, in orthodox Keynesian grounds the assumption about shifts in fixed rates of inflation allows policymakers to attribute unemployment to the attempt for inflation reduction (Friedman, 1968; Phelps, 1967, 1968). Furthermore, the Keynesian Phillips curve is assumed to be flat so as high unemployment rates to be solved through small increases in inflation, contrary to Monetarist Phillips curve that is assumed to be steep enough in order to prove that expansionary demand policies cannot reduce unemployment levels through increases of inflation rates (Espinosa-Vega and Russell, 1997).

Evidently the introduction of inflationary expectations indicates the dependence of inflation on unemployment and expected inflation levels. Moreover, the implied distinction between short and long-run period suggests that only during the short-run trade-off, activist demand policies can be effective since an upward demand shift, according to the usual slope of Phillips curve, pushes actual unemployment below its predetermined natural level. In these conditions, the short-run Phillips curve would be shifted up by taking the equality between expected and actual inflation rate for granted. As long as the natural unemployment rate is affected by labor markets' 
structural characteristics but not by the aggregate demand level, the whole process of trade-off cannot be affected by fiscal policy. All these resulted in viewing the long-run Phillips curve to be vertical and stable at the natural unemployment rate.

\section{III. From Natural Unemployment Rate to NAIRU}

Despite the success of augmented with expectations Phillips curve in solving the problems that economies faced, the severe recession in the mid 1970s as well as the high levels of both unemployment and inflation rates, persuaded many economists for the reappearance of Keynesianism. However, the effectiveness of new classical Phillips curve persuaded Keynesian economists to reinterpret the Phillips curve within a framework that the natural unemployment rate and the accelerating hypothesis with the adoption of demand management policies could be combined; this synthesis led to the development of the new Keynesian economics.

The adoption of new Keynesian framework imposed constraints against the use of augmented expectational Philips curve, which concentrated on squeezing unemployment at levels below its threshold natural unemployment rate, in the presence of accelerating inflation. In addition, according to Modigliani and Papademos: "...the existence of NIRU, the non inflationary rate of unemployment, is implied by both the "vertical" and "non vertical" schools of Phillips curve" (1975, p. 242).

More precisely, Modigliani and Papademos (1975) viewed the use of NIRU as the representation of the relationship between inflation and unemployment; this is determined by the intersection of the downward Keynesian Phillips curve with the vertical Friedman's natural unemployment rate. In these conditions, the NIRU (NonInflationary Rate of Unemployment), that represents a level of unemployment for which inflation is expected to remain constant, is included in the horizontal axis of unemployment level and the vertical axis of inflation rate. As for the intermediate positions of Phillips curve, it was suggested a relatively flat Phillips curve for high unemployment rates and an approximately vertical for low unemployment levels were assumed (Espinosa-Vega and Russell, 1997). Further, in Modigliani and Papademos (1975)'s view, NIRU was interpreted as a constraint in policymakers' ability to exploit the trade-off between unemployment and inflation in the long-run but as an ability to be used during the short-run.

Thus in accordance with the adopted definitions a gradual unemployment 
reduction in a specific time period is implied so as economy to rest upon its predetermined natural unemployment rate, which was re-defined as the non inflationary unemployment rate or simply NIRU. Moreover, the long-run equilibrium level that rests upon the assumptions about money neutrality requires the absence of any trade-off in the long-run and a linear relation between unemployment and inflation; conditions that are determined by the implications of the adopted framework. For instance in monetarist and new classical grounds a vertical Phillips curve implies that unexpected changes in price levels reduce real unemployment rates that are above NIRU regardless of their initial level. On the other hand, a change in the Keynesian downward sloping Phillips curve pushes economy towards a new Phillips curve with respect to the distinction between current and initial inflation levels. In general the philosophy of this new Keynesian concept suggests that any unemployment level below the predetermined NIRU should be followed by inflation reductions and vice versa.

Evidently the transformation of the natural unemployment rate to NIRU changed the form of monetary policies, in the sense that allowed comparing directly the observed unemployment levels with the predetermined natural rates. Additionally actual unemployment level is being used as a good approximate for the behavior of future inflation, as long as low levels of current unemployment are related with future inflation rises in the short-run and inflation acceleration in the long-run. Thus, as Tobin mentions: “...according to the standard augmented Phillips curve' view, rates of price and wage increase depend partly on their recent trends, partly on expectations of their future movements and partly on the tightness...of markets for products and labor. Variations in aggregate monetary demand whether the consequences of policies or other events, affect the course of prices and output and wages and employment, by altering the tightness of labor and product markets and in no other way"; he additionally observes that: "inflation accelerates at high employment rates because tight markets systematically and repeatedly generate wage and price increases... At the Phelps-Friedman natural rate of unemployment, the degrees of resource utilization and market tightness generate no net wage and price pressure up or down and are consistent with accustomed and expected paths, whether stable process or any other inflation rate. The consensus viewed accepted the notion of a non-accelerating 
inflation rate of unemployment (NAIRU)12 as a practical constraint on policy' (1980, p. 23).

Undoubtedly the way that NAIRU is defined and used in the relevant literature rarely differs from Tobin's (1980) implications. For example, according to Tobin (1980) the comparison of actual unemployment levels with their natural rates reflects monetary policies' conditions during the short-run and the structure of future inflation. Furthermore, the adoption of the new Keynesian NAIRU concept implies that for cases where unemployment is below its natural rate, inflation acceleration in the future is possible. Nevertheless, the use of the NAIRU concept is regarded as the most useful instrument for making monetary policy decisions, though policymakers are usually unaware of the mechanisms behind it.

For that reason and since the use of NAIRU concept assumes the adjustment of real wages on both prices and wages, it is implied that in cases where unemployment is below the determined (via intersection between wages and prices) NAIRU level, wages rise faster than the level of expected prices in the wage equation, whereas in the price equation the level of price grows faster than expected wages (Sawyer, 2001). Both of these cases are characterized by upward inflation shifts, the effects of which are reflected on the level of real wages. But the magnitude of these effects depends on the relative size of wage and price inflation and possibly on the responsiveness of wages and prices to unemployment and capacity utilization respectively and on the expectational form.

In particular, the general form of Phillips curve equation that is being used in current literature for estimating NAIRU is the augmented Phillips curve equation that equals to:

(4) $\pi_{t}=\pi_{t}^{e}+\beta(L)\left(u_{t}-\bar{u}_{t}\right)+\delta z_{t}+\varepsilon_{t}$

where, $\pi_{t}$ : inflation rate from $t-1$ to $t$

$\pi_{t}^{e}:$ inflation rate expected at $t-1$

$u_{t}$ : unemployment rate at time $t$

12 Tobin (1980) instead of using the term NIRU, he used the widely known nowadays term of NAIRU (Non-Accelerating Inflation Rate of Unemployment) without changing its core assumptions. 
$\bar{u}_{t}$ : natural rate of unemployment at time $t$, which could be a constant but could shift with structural changes in the economy

$z_{t}$ : a vector of variables such as supply shocks, which have zero ex ante expectations $^{13}$

$\varepsilon_{t}:$ an unspecified disturbance term

In empirical grounds the above equation is estimated under the assumption that inflation is measured as a distributed lag on past inflation and other variables, while it is also assumed that the variable of inflation rate is integrated of order one, in order the difference between actual and expected inflation to be stationary. Equation (4) can be therefore equally rewritten as:

$$
\Delta \pi_{t}=\beta(L)\left(u_{t}-\bar{u}_{t}\right)+\gamma(L) \Delta \pi_{t-1}+\delta^{\prime} z_{t}+\varepsilon_{t}
$$

where, $\Delta \pi_{t}$ : denotes the differences between inflation rates of current and past period.

In this case, NAIRU is represented by the term $\bar{u}_{t}$ that can be represented either as a constant, a random walk, a linear transformation of some step function or spline process (Staiger et al., 1997b). But as long as NAIRU is the guide for monetary policy, the adopted policies should be determined relative to the unemployment gap between actual unemployment and NAIRU levels ${ }^{14}$; besides, such a distinction is being used as an indicator for future inflation ${ }^{15}$. In any case, the form of augmented Phillips curve that is being used for policy decisions includes the "accelerationist hypothesis" since unemployment can be below NAIRU level only in the presence of a price acceleration without any limit.

13 The introduction of the vector $z_{t}$ of the supply side variables is attributed to new classicals since until then Keynesians concentrated their attention on aggregate demand side and recognized only a limited role for supply side effects on economic activity.

${ }^{14}$ According to Ball and Mankiw (2002), the level of output gap is the key determinant of inflation behavior under the assumption that all the factors that impress inflation are reflected on lagged values of inflation and variables of the $z_{t}$ vector.

15McDonald (1995) claims that the natural rate theory prevents the use of the size of inflation as an indicator for whether economy lays on its equilibrium level or not, whereas the relation between actual and natural unemployment is generally used as an indicator for future inflation behavior. 
The argument that NAIRU is determined by supply side factors suggests that its level can be affected only through them, while according to new Keynesian literature the unemployment gap can be eliminated (except in the case where actual unemployment is close to NAIRU) by changes in labor market; some of these are represented by softening minimum wage restrictions, taxes on labor and restrictions on hiring and discriminatory or other impediments to hire either by reducing or eliminating unemployment benefits by upgrading education and training of workers and perhaps by offering subsidies to new hiring that will be examined below.

\section{IV. Similarities and differences between the Natural Unemployment Rate and NAIRU}

It is widespread the view amongst economists either about the synonymy between natural unemployment rate and NAIRU terms or the treatment of the new Keynesian NAIRU theory as the reformulation of monetarist natural unemployment theory. As a consequence, despite the contradiction of this concept to monetarists' and new classicals' rejection of a possible trade-off between unemployment and inflation, NAIRU is thought to be an alternative expression for the natural unemployment rate. In practice a comparison between the basic characteristics of these two approaches, makes clear their between distinction and provide evidence about the efficiency and the correctness of their implied policies.

Besides, the fact that the Phillips curve is being used as a guide for making policy decisions in both the natural unemployment and NAIRU does not imply similarities in their implications. On one side the use of natural unemployment rate as a policy guide requires the absence of any variation in the long-run stability as well as the absence of expectational errors about wages and prices (Espinosa-Vega and Russel, 1997; Karanassou and Snower, 1997). On the other hand, the fact that the NAIRU level itself is the long-run equilibrium that determines an unemployment level consistent with a constant inflation rate, suggests that at the equilibrium actual and expected inflation rates and thereby actual and natural unemployment levels are equal so as the behavior between wage and price setters to be competitive (Solow, 1986).

Further Friedman's natural rate is a market clearing concept, while in accordance with implications of NAIRU concept the long-run equilibrium level is determined by the balance of power between workers and firms thus theories of 
imperfect competition in the labor and production markets are related (Snowden et al., 1994). This distinction stems from the fact that in the natural unemployment rate economies are assumed to operate according to a Walrasian process that refers to perfect competitive conditions, whereas in NAIRU grounds imperfect competitive conditions are recognized (Jekinson, 1987). In this case, the adoption of the natural unemployment hypothesis implies that economy always returns to its natural rate without any inflationary pressure, whereas in accordance with NAIRU concept the presence of persistently unemployment levels above the predetermined NAIRU stands as a result of markets' failure to be cleared (Tobin, 1995, 1998; Galbraith, 1996). Besides, in the new Keynesian interpretation the NAIRU concept depends on labor market institutions that determine wage claims and on the market power of firms that set the price level.

All these are closely related with the way that unemployment is being treated in each of these two concepts. The treatment of unemployment as a voluntary in terms of natural hypothesis unemployment suggests the absence of any equality between actual unemployment levels with its natural and reflects people's decisions about the way they decide to spend their time between leisure and working hours. On the other hand, in NAIRU framework unemployment's treatment as involuntary, which equilibrium level is theoretically determined by the characteristics of labor market, is set in order to set inflation under control (Layard et al., 1991). Obviously, the Monetarist natural rate of unemployment is not a NAIRU theory in the strong sense, even though the policy recommendations based on the NAIRU are coincided with Monetarist policies. Alternatively, the precondition for NAIRU and natural unemployment rates synonymity is either the presence of a vertical long-run Phillips curve or the inclusion in NAIRU definitions of the lagged inflation coefficients (Solow, 1986).

In addition, it should be regarded the ability of explaining the natural unemployment rate as a microeconomic phenomenon since it can be thought to lie implicitly onto individual's decisions and behavior is also of vital importance. Contrary to this, NAIRU includes both macroeconomic and microeconomic foundations that concern price and wage behavior so as inflation to be constant. This is explained by considering that the natural unemployment rate within monetarism grounds rests on the assumption about the competitiveness of labor and product markets, whereas in 
imperfect competitive new Keynesian markets the presence of persistently high unemployment is attributed to markets' failure (Tobin, 1995).

Particularly, we should always consider that Friedman's and Phelps' natural unemployment rate is defined as the equilibrium level whose value is determined by the characteristics of labor market, whereas NAIRU is simply an empirical rather than an equilibrium value. In no case, should be ignored that the natural unemployment rate is a theoretical magnitude toward which actual unemployment is assumed to move, though it cannot be estimated, whereas NAIRU can be indirectly determined and easily estimated under specific assumptions (Karanassou and Snower, 1997). Thus, despite similarities in policy implications in the sense that Friedman (1968) and Phelps (1968) laid the cornerstone for the later discussions of the NAIRU by proposing the long-run vertical Phillips curve, the Monetarist natural rate theory should be characterized a distinct theory and not a variant of the NAIRU theory. This reflects the fact that each of these frameworks is consistent with different policy implications, regardless of the indirect observation and estimation of both them.

\section{NAIRU and unemployment: which is their actual relation?}

The dependence of unemployment policies on NAIRU and its implications that stem from the Phillips curve is explicitly analyzed in the previous sections. As we have already mentioned, though the treatment of supply side NAIRU concept is considered to be the policy reference point in the sense it expands economy, it pre-requires the balancing of the dangers of inflation (Solow 1998; Ball and Mankiw, 2002). In this manner, the common characteristic of economies is the consistency of NAIRU concept with inflation targeting policies so as inflation and inflationary expectations to be tamed and economies to be kept at their natural rates of unemployment; in this case unemployment is recognized as an indicator of future inflation ${ }^{16}$. Usually the adoption of this regime is coincided with the use of feedback rules ${ }^{17}$ that intent to push economies towards the adopted inflation target; which is assumed to be the optimal

\footnotetext{
${ }^{16}$ Considering new Keynesians' adherence on inflation as the main source for accelerating economic activity within NAIRU framework, it is proved their consistency with Friedman's (1968) suggestion about the treatment of inflation as a purely monetary phenomenon towards which output levels can be adjusted (Solow, 1998; Ball and Mankiw, 2002).

17Feedback rules suggest the absence of any long-run trade-off between unemployment and inflation within the NAIRU concept (Taylor, 1998; Clarida et al., 1999).
} 
one and to aim at a lower inflation level than the existent (Taylor, 1998; Clarida et al. 1999) 18 .

In practice, the achievement of inflation targets is related with the appropriate treatment of short-run nominal interest rates (Solow, 1998; Galbraith, 1997); a thought that is consistent with Friedman's (1968) suggestion about the treatment of monetary policy as the most appropriate instrument for stabilizing economies ${ }^{19}$. Nowadays the most widely used mechanism through which interest rate affects inflation and economic activity is the known as Taylor's (1993) rule ${ }^{20}$. This is an interest rate rule, which employs the short-run nominal interest rate in order to stabilize inflation via its relation with the behavior of real GDP and money growth. According to Taylor's rule, the use of short-run nominal interest rate stabilizes inflation via its relation with the behaviour of real GDP and money growth. In other words, nominal interest rates are being treated so that expected nominal income rests at a level close to its target. The general form of Taylor's rule equals:

(4) $r=p+5 y+5(p-2)+2$

where $r:$ the federal funds rate

$p:$ the rate of inflation over the previous four quarters

$y:$ the percent deviation of real GDP from a target, that is, $y=100\left(Y-Y^{*}\right) / Y^{*}$

with $Y$ the real GDP and $Y^{*}$ the trend of real GDP

The feature of this rule is that federal funds rise when inflation is above the adopted target, which in Taylor's (1993) view equals $2 \%$, or when real GDP rises above its trend. If both inflation and real GDP levels rest on their target, the federal funds rate would be equal to $4 \%$ or $2 \%$ in real terms. On the other hand, in cases where

\footnotetext{
18Despite the constraints that are raised from the downward rigidities of wages or prices that cause further price adjustment, policy targets can refer to both low inflation and high stabilized output levels (Debelle, 1997).

19In Friedman's (1968) view the natural unemployment rate is defined as the distinction between nominal and real interest rates equals the inflation level, whereas upward shifts of short term interest rates intend to provoke economic slowdown and feed inflation reductions through tight money policies.

20Taylor's rule reflects economic activity of many economies from 1987 onwards (Clarida et al. 2000).
} 
monetary authorities use the short run nominal interest rate, their targets and thereby the paths to achieve them should be set with regard to actual economic conditions. In other words the use of Taylor's rule suggests a positive weight on both the price and real output levels.

However, the increasing degree of economic globalization in conjunction with the high degrees of uncertainty that characterizes the effects from the adoption of interest rate policies, suggest that monetary authorities should regard their decisions by taking into account counter-inflation action, in the sense that it is preferable to follow policies that aim at educing high inflation levels before the presence of accelerating inflation levels; this is known as "long-lag response". But policymakers should also be aware of the "genie-and-the-bottle response" form of policy that suggests the adoption of policies whose results are unexpected because of their inability to control the non linear relation between inflation and unemployment levels, when the former is relatively high. In any case, policymakers apart from concentrating on the magnitude of inflation in order to improve economic activity in terms of employment should also take into consideration the actual needs of economies in order to limit the possibility for making incorrect policy decisions (Solow, 1998). For that reason, it is believed that policymakers should be able to limit the uncertainty of their policy effects and be characterised by freedom if their intervention is required (Solow, 1998). Hence, we should take into account that the behavior of interest rate policy rules depends on the adopted monetary regime (Taylor, 1995, 1999; McCallum, 1984).

Particularly the consequences of disinflation policies are determined in relation to the equilibrium natural unemployment rate as well as the degree of validity and uncertainty included in the behavior of inflation. Nevertheless, new Keynesians' concentration on inflation targeting rules is possible to lead economies to a transitory period, during which current inflation rates move towards targeted inflation and thereby output stabilization (Bernaske and Mishkin, 1997). Although, it is possible for inflation itself to be affected by unemployment shocks (Mankiw, 2001)21, it is also possible policy targets, with respect to the uniqueness of inflation targeting framework, to be achieved without causing additional problems (Taylor, 1993; Clarida et al., 1999). Besides, the assumptions about money neutrality and long-run Phillips

21This case refers to long-run term during which unemployment shocks are raised by monetary authorities' attempt to refrain from being forward looking and responding to inflationary pressures even before inflation arises (Mankiw, 2001). 
curve verticality increase the degree of independency of the adopted NAIRU level from inflation behavior (Solow, 1998; Tobin, 1995).

But the concentration on inflation targeting regimes and the uncertain results of the adopted monetary policies instead of expanding economic activity pushes it into a circle of continuous recessions and unemployment expansions (Solow, 1998; Taylor, 1998). There are economists such as Fitoussi et al. (2000), Phelps and Zoera (1998) and Bean et al. (1986) who characterize the use of real interest rates as the most representative monetary instrument, though sets monetary policies only partially responsible for the persistent high levels of unemployment across economies. In addition, Fischer (1993) provides evidence for a positive correlation between price stability and economic growth, while Romer and Romer (1999) declare that the American economy in the long-run has been characterized by low inflation levels and macroeconomic stability as well as by high degrees of income inequality.

Contrary to these suggestions, Fortin (1996) indicates the absence of any correlation between inflation and unemployment or of their growth rates to the heterogeneity of characteristics across sample economies; results that are proved by Easterly and Fischer (2001) for the case of poor societies. Moreover, according to Ball (1997) the possibility a fully credible disinflation to be related with an economic boom cannot be rejected, despite the high uncertainty that characterizes disinflationary policies for both low and high inflationary economies. However, when disinflation booms are announced and credible, firms are supposed to respond by reducing their prices, while a rise in money balance that will cause a rise in output but an unemployment reduction is also possible (Mankiw, 2001). Even if the consequences of disinflation policies are ex ante recognized, attention should be paid on the qualitative characteristics of economies in order to provide evidence about their significant impact on economic performance (Fortin, 1996).

But the concentration of policymakers on disinflation policies introduces the presence of hysteresis phenomenon 22 ; a common characteristic for European and OECD countries during the 1980s (Ball, 1994; Berger and Everaert, 2008). Thus, it

22 The phenomenon of hysteresis implies the persistence of unemployment that gradually pushes upward the natural unemployment rate by reducing available jobs and job-search skills of both employed and unemployed routes (Blanchard and Summers, 1987). It should be mentioned that one of the fundamental characteristics of hysteresis the depreciation of human and physical capital that causes, at levels that cannot possibly be regained by workers (Ball et al., 1999). 
can be said that the upward shift of NAIRU between the 1980s and the 1990s in these countries is explained by the combination of long run disinflation policies and a generous unemployment system, although there is no empirical evidence to suggest the existence of hysteresis. These suggestions are enforced by the fact that hysteresis is usually attributed to the political responses of unemployment changes through the adoption of social governments programs and insurance programs about the unemployed (Ball, 1994; Blanchard and Summers, 1987).

Notwithstanding, the negative consequences on unemployment from the adoption of disinflationary policies are mainly raised by the way that unemployment is being treated. As we have already mention in the previous sections, in the majority of current new Keynesian literature the persistently high unemployment levels are usually attributed to institutional characteristics of labor markets, the different characteristics and conditions across economies as well as to macroeconomic shocks that take place, though there are some institutions that lead to employment expansion (Blanchard and Wolfers, 2000; Blanchard and Katz, 1997; Baker et al., 2004; Glyn et al., 2004; Nickell, 1997, 1998). All these contribute to the adoption of unemployment policies that are associated with labor market rigidities namely increases in the union power, the mismatching between the demand and supply of labor, the effects of increasingly generous unemployment benefits, increases in reservation wages and the market power that stem from the especially high interest rates and demographic developments (i.e. Nickell, 1997, 1998; Fitoussi et al., 2000; Siebert, 1997; Phelps and Zoera, 1998; Baker et al., 2004; Glyn et al., 2004; Bean, 1994; Layard et al., 1991). In no case should be considered the uniqueness of characteristics across economies; it is exactly the existence of these differences in macroeconomic institutions that diverges the employment trends across economies.

It is clear that supply side factors and differences in institutions and social characteristics of each market have played an important role. Generally the difference in the degree of significance of labor market rigidities in explaining unemployment are attributed to differences in the form and the structure of domestic shocks that characterize each economy and thereby its response to them (Phelps and Zoera, 1998) as well as to regional unemployment disparities (Bande and Karanassou, 2007). Despite the thought that within NAIRU framework labor market institutions create a friendly environment for employment, in practice are proved to be responsible for 
expanded unemployment; there are also 'good' institutions (i.e. coordination variable, active labor market policy) that create the appropriate conditions for employment and economic expansion, though the level of their efficient is not always plausible.

The quite mixed evidence about the impact that labor market institutions have on unemployment as well as the degree of their significance in explaining it, can be attributed to the fact that researchers use different measurement and estimation methods as well as different data about the used variables. Although there is no direct linkage among labor market institutions and macroeconomic shocks with actual unemployment levels, with respect to heterogeneity of each economy their presence appears to explain the persistently high unemployment levels across economies adequately. It can therefore be said that the explanation of persistently high unemployment levels in accordance with NAIRU implications is in many cases problematic. Consequently the necessity that arises, concerns the appropriateness of mix labor market institutions and laws that will actually protect employment. The inconsistency between theoretical implications of NAIRU and economic reality as is represented by growth and employment rates in conjunction with the inability of the implied policies to control unemployment, especially nowadays, set the degree of NAIRU appropriateness to be questioned. Besides, the correct mix of labor policies for each economy should be determined with respect to their actual needs and conditions and even by considering other sources for facing unemployment.

\section{NAIRU estimations and methodological issues}

Despite the general acceptance of NAIRU as a policy guide the fact that its use is usually related with unexpected consequences on economic activity, raise a number of questions about its appropriateness. Although some economists (e.g. Stiglitz, 1997; Blanchard and Katz, 1997; Ball and Mankiw, 2002) view the NAIRU concept as a useful piece of business cycle theory, for others such as Chang (1997) this is only a framework for predicting inflation, understanding its causes and therefore making employment policies. Further, the possibility for the whole idea of NAIRU to be harmed if inflation, wages and unemployment do not behave together or even more in times of low inflation the Phillips Curve not to be vertical, raise additional questions about the appropriateness of using NAIRU (Franz, 2003). In particular, the criticisms 
about the technical part of NAIRU estimations stem from the fact that it is a theoretical argument that rests upon a non-theoretical foundation.

The cornerstone about NAIRU criticism is that its level can only indirectly be observed through estimations about the long-run unemployment equilibrium point; an argument that imposes no constraints in methodologies, variables and approaches that are employed for estimating NAIRU. For that reason, it is recognized the sensitivity of NAIRU estimations on the assumptions of the adopted framework as well as on the employed specifications, the sample period and data as well as the included variables and estimation method. In this manner, even the number of included lags is essential, since it reflects the degree and form of included information; the lower their number the closer to actual economic conditions NAIRU estimations turn out to be (Galbraith, 1997; Gordon, 1997; Franz, 2003). Hence when lags refer to the variable of inflation or economies are characterised by favorable supply side shocks, inflation deceleration is possible to come up; in both cases inflation decelerates even when actual unemployment is below its natural level. For the case where lags refer to the variable of unemployment the presence of more complicated dynamics that ensure the association of a current unemployment reduction with decelerating inflation is implied (Estrella and Minshkin, 1999). For that reason, many economists such as Staiger et al. (1997b), Stiglitz (1997), Rogerson (1997), recognize the direct effects of the included number of lags on the variable of unemployment as well as the presence or not of contemporaneous unemployment values on NAIRU estimations. In any case the number of lags for included variables reduces the degree of standard errors and affects the estimated coefficients importantly (Fair, 1997).

In addition, the form of included expectations in the augmented-expectational Phillips curve affects NAIRU estimations as well as the degree of policymakers' confidence about the adopted targets definitely. The fact that new Keynesians have no unique view of the form of included expectations ${ }^{23}$, though in recent literature there is a preference on adaptive expectations in the sense that they perform sufficiently and their implications are similar to those of rational expectations, allows expectations to

\footnotetext{
${ }^{23}$ Their view rests somewhere between the adaptive and rational expectations, since Keynes (1936) suggests that expectations are essentially affected by social conventions, whereas according to Lucas (1972) rational expectations provide the opportunity to workers to decide upon their working hours. In general both the inflation and unemployment policies are directly determined by the way that expectations are formed.
} 
have an outstanding role in determining policy decisions (Ball and Mankiw, 2002). Although, the introduction of adaptive expectations in Phillips curve seems to be adequate in providing a perfect fit for the stylized facts of monetary macroeconomics, so as monetary shocks to affect unemployment, it is also possible the effects of these shocks to be reflected on inflation with some delay (Mankiw, 2001). It is therefore obvious that expectations affect the assessment of future inflationary pressures, though it is argued that the NAIRU concept loses its simplicity if inflation expectations are taken into account, since inflation level itself might change due to inflation expectations which are unrelated to deviations of unemployment from the NAIRU (Chang, 1997). Regardless the form of included expectations in Phillips curve equation, it is required the introduction of lagged inflation term (Ball and Mankiw, 2002)24.

But NAIRU estimations are also affected by the adopted method of inflation and unemployment measurement (Staiger et al., 1997b; Ball and Mankiw, 2002). Apart from the unemployment and output gap that are widely used as indicators of future inflation, there is a range of alternative and possibly more appropriate measures (Nickell, 1990; Estrella and Minshkin, 1999; Schreiber and Wolfers, 2007). For example, Stock and Watchon (1999) have concluded that inflation estimations with respect to Phillips curve are more accurate relative to others, while in Stock and Watchon (1996) signify the presence of, at least, sixty nine alternative indicators that can be used for inflation prediction and provide different information and thus inflation predictions. Further, it has been found that the use of unemployment as an indicator of inflation predictions is characterized about its impropriety, while the alternative ways of measuring it reduce the degree of uncertainty in forecasts (Gordon, 1988; Claar, 2006). The absence of any proper inflation measure is verified by the fact that in Phillips curve literature gross domestic product is widely used as an indicator of 'core inflation' by excluding prices of foods and energy goods (Staiger et al., 1997a). In practice however there is no qualitative information about both inflation and unemployment across economies.

It should be however be mentioned that essential role for the determination of NAIRU estimations and implications also has the way that unemployment is being

${ }^{24}$ The advantage of adaptive expectations is the ability to treat the natural unemployment rate as the NAIRU level in order both the stability of inflation between two period and the absent of supply shocks to be ensured (Ball and Mankiw, 2002). 
proxied. In recent literature unemployment and its long run equilibrium are approached with respect to Say's Law and supply side factors. The fact that Say's Law allows economy to correspond to its full employment and capacity utilization, provides the opportunity to contemplate the way that supply can be compared with demand ${ }^{25}$. Besides, the use of models of bargaining power efficiency wages and insiders-outsiders and the implied rigidities and imperfections in labor markets for explaining unemployment, turn out to be incorrect ${ }^{26}$ levels (Blanchard and Katz, 1997).

Another methodological issue for NAIRU estimations concerns its treatment as constant or time varying, though in recent literature NAIRU is considered to be a time variant. Thus in a number of estimations, NAIRU ranged around 3.5\% in mid-1960s, reached its peak during 1980 s at the level of $7.25 \%$ and fell at the level of $5.75 \%$, while in the recession of 1990s NAIRU estimations set it around 6\% (Staiger et al., 1997a, 1997b; Rogerson, 1997; Gordon, 1997; Stiglitz, 1997; Galbraith, 1997). Nowadays, both American and European time varying NAIRU levels are set close to $5.5-6 \%$ or even lower, despite the incorrectness that is included in NAIRU forecasts even under its time variance (Staiger et al., 1997a)27. In general, Staiger et al. (1997b), imply that NAIRU can be presented as a constant or spline or even as a break procedure or as being determined simply by its previous levels ${ }^{28}$.

But the presence of constant or time varying NAIRU has consequences in terms of economic policies, the most essential of which is the degree of their correctness. To be more specific, the treatment of NAIRU as constant or time-variant raises additional difficulties for monetary authorities, in the sense that policy decisions are made with respect to its predetermined level (Collignton, 2003). On the other hand, the

${ }^{25} \mathrm{~A}$ possible way to do this is to consider the value of marginal propensity to spend that requires its equality to unity in order for Say's Law to hold without the presence of any problem (Sawyer, 2001).

26The common characteristic of these models is the implied positive relation between unemployment and wage levels that is being used as the determinant of unemployment levels (Blanchard and Katz, 1997).

27According to Friedman (1968) a shift of NAIRU level itself is determined by changes either in demographic compositions or in technological and hence changes in productivity levels; suggestions that are adopted even nowadays. In recent literature, such as Ball and Mankiw (2002) and Gordon and Stock (1998), the introduction of 'new technology' refers to speedy development of new technologies, openness of the competition and trade among countries as well as to the increase of the productivity growth rate, turns to be the most significant reason for shifting NAIRU levels.

28In recent literature the time variance of constancy of the NAIRU level can be examined by employing Gordon's (1997) “triangle model'. 
assumption of a time variant NAIRU, although raises the difficulty for making policy decisions, it contemporaneously raises the degree of their correctness; besides the correctness of policy suggestions is highly depended on the length of the period to which observed data and estimations are referred (Galbraith, 1997; Gordon, 1997). Furthermore, the adoption of a time variant NAIRU is supposed to provide the adequate conditions for the adoption of techniques that reduce the degree of uncertainty (Clark and Laxton, 1997). In no case, should the adoption of a time varying NAIRU and its shifts be considered as changes in actual unemployment level (Blinder, 1997).

Due to the absence of any guidance on NAIRU behavior and the incomplete knowledge of its implications, in mainstream grounds it is possible to assume the slow adjustment of NAIRU to changes (Staiger et al., 1997a, 1997b). Besides, policy decisions rest upon NAIRU constancy and its equality with actual unemployment level so as policy decisions about inflation to provide the expected results. In any case, in the process of policy determination monetary authorities should consider whether the average rate of unemployment, that is usually adopted, is being affected by monetary policies. If this stands, the natural rate cannot be posited as completely exogenous and the neutrality hypothesis would not apply even in the long-run (Collignton, 2003). In other words, the essence of any monetary policies suggestions is cancelled out.

Closely related with the tendency to treat NAIRU as a time varying, is also the assumption about its uniqueness; an issue that concerns the degree of NAIRU correctness in new Keynesian grounds. More specifically, the information that is provided by the NAIRU variance over time is cancelled out by assuming its long-run uniqueness (Staiger et al., 1997a). However, in new Keynesian theory there is no reference about the possibility of NAIRU concept to be characterized by multiple equilibria, although this is directly implied by considering the 'usual' phenomenon of hysteresis (Ball, 1997). The assumption about NAIRU uniqueness stems from the suggested consistence of natural unemployment rate with market clearing and the inverse relation between unemployment and real wages. However, the consistency of new Keynesian economics with a range of models and thereby theoretical implications, makes the existence of multiple rather than unique equilibrium more convincing (Sawyer, 1998, 2001). Besides, it is exactly the combination of the assumptions about multiple equilibria and hysteresis that distinguishes new classical from new 
Keynesian economics, although the latter rest upon a range of new classical assumptions (Sawyer, 2001). Indeed, the assumption about a unique employment and output equilibrium level is relatively strict, while such equilibrium is possible to be biased because of the specific assumptions upon which it lies (Dixon, 1995). Nevertheless the assumed uniqueness of supply side NAIRU and neutrality conditions set the dominance of new classical implications despite its incorrectness ${ }^{29}$.

Additionally, the determination of natural unemployment level in accordance with Wicksellian natural interest rate, so as equilibrium to be simultaneously determined in both labor and capital markets, enriches the dynamic adjustment that raises the possibility of multiple natural equilibria (Dixon, 1995). As a consequence, the suggestions against NAIRU uniqueness cast doubts on its use as a benchmark for monetary policy and as the appropriate instrument for achieving price stability. Regardless of the uniqueness or not of NAIRU, it should be considered that the implied equilibrium is neither competitive nor Pareto optimal and thereby cannot reflect real abilities of economy (Dixon, 1995). Besides, its presence becomes inconsistent at high unemployment rates for which multiple equilibria are highly possible (McDonald, 1995). Obviously, the way that unemployment is defined as well as the suggestion about whether its estimations include a whole set of unemployment levels each of which is associated with different values, affects the presence or the absence of unique equilibrium definitely.

All these are essential for the conduct of monetary policies, given that in new Keynesian grounds policy decisions are determined with respect to interest rate rules and implicitly by the acceleration model (NAIRU). Further, the inability to separate among the structural characteristics of unemployment and simply treat NAIRU as the magnitude that reflects actual unemployment makes the absence of any policy solution about the unemployment problems reasonable. Thus, by regarding a specific value for NAIRU, it is certain that the achievement of policy targets will affect economies mischievously, regardless of the uncertainty about the correctness of these policies.

The implied uncertainty and doubts that characterize NAIRU concept and its estimating process enforce the thought of solving high unemployment and inflation

\footnotetext{
29Usually this equality is accepted regardless of whether or not economists are aware of the factors that determine the marginal product or the differences between theoretical and empirical grounds (Sawyer, 1998).
} 
levels by using short-run Phillips curve (Demertzis and Hallett, 1995; Dixon, 1995) ${ }^{30}$. Besides, historically there is no explicit NAIRU level that characterizes economies, whereas the dependence on labor market conditions and specifications is widely accepted, although there are few empirical studies that prove its existence in real economies (Tobin, 1980). Moreover, the use of short instead of long-run Phillips curve to make policy decisions seems to reflect actual economic conditions perfectly, while its implications raise the possibility of improving economy's performance and providing Pareto optimal results. Such consideration is enriched by the possibility many economies not being characterized by an explicit long-run relation between inflation and unemployment. In addition, the fact that the concentration on long-run equilibrium level and the use of unemployment gap can provide limited useful policy suggestions should be also considered (Estrella and Minshkin, 1999).

In any case policymakers are called to be well aware of the mechanisms that characterize NAIRU, namely the adopted methods for its estimations as well as the included variables in order for policy suggestions to reflect real economies (Solow, 1998). The thought that NAIRU sets the consistency between inflation reductions and economic growth suggests that unemployment reductions can be achieved through changes in structural and cyclical characteristics of labor market due to changes in the participation level and the required skills that should characterise workers or even demand weaknesses (Summers et al., 1986). Nevertheless, the achievement of full employment cannot be ensured by considering the equality of real wages at their natural levels (Hall, 1975).

Despite the criticism about the correctness of NAIRU supply side framework that mainly concerns its inability to reflect real economies, this framework is still considered by economists and policymakers as the theoretical benchmark for stabilizing monetary policies. However the questions raised above, concern not only the correctness of NAIRU estimations but also the correctness of policies that stem from its use, which are proved to provide only sub-optimal suggestions. The problem of these policies is not to persuade the public about their advantages but to provide evidence against its imprudent consequences on economic activity. Besides, what is really required is the adoption of policies that reflect actual necessities of economies so as the targets of price stability and full employment to be reached without harmful

${ }^{30}$ In accordance with these suggestions Batini and Greenslade (2006) measured the short run NAIRU for the British economy. 
consequences in economic activity. It thereby seems accurate to adopt an alternative and more realistic framework which would be recognized an active role for aggregate demand. In other words, the adoption of a framework that would account for all the problems stemming from NAIRU concept in order for promoting employment and economic expansion, seems to be reasonable. In any case, the adoption of an alternative NAIRU framework should be easily understood and widely accepted.

\section{Conclusion}

The burst of the current worldwide economic crisis and the ensuing drop in economic activity and employment came as a big surprise to economists and policymakers who make employment decisions. But the increasing degrees of globalization and the coherence on inflation targeting regime and NAIRU concept that has changed the structure of macroeconomic behavior are in some degree responsible for economic stagnation. However, the emergency of current economic conditions make clear that there is no elbow room for using anymore NAIRU as a policy guide for determining employment, unless positive contributions by labor market regulations are taken into account. This is because of the incomplete knowledge that most of economists and policymakers have about the theoretical grounds of NAIRU framework. What it is actually required for facing unemployment, is to consider the actual conditions and needs of economies without rejecting the demand side of each economy and being concentration on a purely supply side environment as it is done with the adoption of NAIRU.

It is time to understand that the main reason for persistent unemployment levels is the low degree of realism that characterizes employment policies as well as the shortage of demand that is caused by them. Hence, what it is actually required is the understanding of the core of economic theories and their conjunction with the ongoing problems of economic activity.

\section{References}

Baker, D. Glyn, A. Howell, D. and Schmitt, J. (2004). Unemployment and Labor Market Institutions: The Failure of the Empirical Case for Deregulation, New School CEPA papers, September 2004.

Ball, L. (1994). Credible Disinflation with Staggered Price Setting. American Economic Review, Vol. 84(1), 282-289. 
Ball, L. (1997). Disinflation and the NAIRU, in C. Romer and D. Romer (eds), Reducing Inflation: (167-194), University of Chicago Press, Chicago.

Ball, L. and Mankiw, G. N. (2002). The NAIRU in Theory and Practice. Journal of Economic Perspectives, Vol. 16(4), 115-136.

Ball, L. Mankiw, G. N. and Nordhaus, W. D. (1999). Aggregate Demand and Long Run Unemployment. Brookings Papers on Economic Activity, Vol. 199(2): 189-251.

Ball, L. and Sheridan, N. (2003). Does Inflation Targeting Matter? NBER Working Paper Series, No.9577, National Bureau of Economic Research, Cambridge, MA.

Bande, R. and Karanassou, M. (2007). Labor Market Flexibility and Regional Unemployment Rate Dynamics: Spain 1980-1995. Institute for the Study of Labor (IZA), Discussing Papers Series, No. 2593.

Batini, N. and Greenslade, J.V. (2006). Measuring the UK short-run NAIRU. Oxford Economic Papers, Vol. 58(1), 28-49.

Bean, C. R. (1994). European Unemployment: A Survey. Journal of Economic Literature, Vol. 32(2), 573-619.

Bean, C. Layard, R. and Nickell, S. (1986). The Rise in Unemployment: A MultiCountry Study. Economica, Vol. 53(210), Supplement: Unemployment, 1-22.

Berger, T. and Everaert, G. (2008). Unemployment Persistence and the Nairu: A Bayesian Approach. Scottish Journal of Political Economy, Vol. 55(3), 281-299.

Bernaske, B.S. and Mishkin, F.S. (1997). Inflation Targeting: A New Framework for Monetary Policy. Journal of Economic Perspectives, Vol. 11(2), 97-116.

Blanchard, O.J. and Wolfers, J. (2000). The Role of Shocks and Institution in the Rise of European Unemployment: The Aggregate Evidences. Economic Journal, Vol. 110(462), Conference Papers, 1-33.

Blanchard, O. J. and Katz, F. L. (1997). What We Know and Do Not Know About the Natural Rate of Unemployment. Journal of Economic Perspective, Vol. 11(1), 5172.

Blanchard, O.J. and Summers, L.H. (1987). Hysteresis in Unemployment. European Economic Review, Vol. 31(1-2), 288-295.

Blinder, A. S. (1997). Is There a Core of Practical Macroeconomics That We Should All Believe? American Economic Review, Vol. 87(2), 240-243.

Chang, R. (1997). Is Low Unemployment Inflationary? Economic Review, Federal Reserve Bank of Atlanta, Issue Q I, 4-13, Atlanta. 
Claar, V.V. (2006). Is the NAIRU More Useful in Forecasting Inflation than the Natural Rate of Unemployment? Applied Economics, Vol. 38(18), 2179-2189.

Clarida, E. Gali, J. and Gertlet, M. (2000). Monetary Policy Rules and Macroeconomic Stability: Evidence and Some Theory. Quarterly Journal of Economics, Vol. 115(1), 147-180.

Clarida, E. Gali, J. and Gertlet, M. (1999). The Science of Monetary Policy - A New Keynesian Perspective. Journal of Economic Literature, Vol. 37(4), 1661-1707.

Clark, P. and Laxton, D. (1997). Phillips Curves, Phillips Lines and the Unemployment Costs of Overheating, IMF Working Paper 97/17.

Collignton, S. (2003). The Role of Monetary Policy in Setting the Natural Rate of Unemployment, paper prepared to be presented at Workshop Quantitative Prognosen realwirtschaftlicher Effekte der Gelpolitik, Berlin.

Debelle, G. (1997). Discussion of Design Inflation Targets. Reserve Bank of Australia, Sydney.

Demertzis, M. and Hallet, A.H. (1995). Is the Natural Rate of Unemployment a Useful Concept? in R. Cross (ed), The Natural Rate of Unemployment (315-345), Cambridge University Press, Cambridge.

Dixon, H. (1995). Of Coconuts, Decomposition and a Jackass: The Genealogy of the Natural Rate, in R. Cross (ed), The Natural Rate of Unemployment (57-74), Cambridge University Press, Cambridge.

Easterly, W. and Fischer, S. (2001). Inflation and the Poor. Journal of Money and Credit and Banking, Vol. 33(3), 160-178.

Estrella, A. and Mishkin, F. S. (1999). Rethinking the Role of NAIRU in Monetary Policy: Implications of Model Formulation and Uncertainty, in J.B Taylor (ed), Monetary Policy Rules, (405-435), NBER- Business circles Series, Cambridge, MA.

Espinosa-Vega, M.A. and Russell, S. (1997). History and Theory of the NAIRU: A Critical Review. Economic Review, Federal Reserve Bank of Atlanta, Atlanta.

Fair, R. C. (1997). Testing the NAIRU Model for 27 Countries. Cowles Foundation, Yale University, March, 1-32.

Fischer, I. (1926). A Statistical Relation Between Unemployment and Price Changes. International Labor Review, Vol. 13(6), 785-792.

Fischer, S. (1993). The Role of Macroeconomic Factors in Growth. Journal of Monetary Economics, Vol. 32(1993), 485-512. 
Fitoussi, J.-P. Jestaz, D. Phelps, E. and Zoega, G. (2000). Roots of the Recent Recoveries: Labor Reforms or Private Sector Forces? Brookings Papers on Economic Activity, Vol. 2000(1), 237-331.

Fortin, P. (1996). The Unbearable Lightness of Zero Inflation Oprimisism, in B. K MacLead and L. Osberg (eds), The Unemployment Crisis (14-38), McGill-Queen's University Press, Canada.

Franz, W. (2003). Will the (German) NAIRU Please Stand up? Zentrum für Europäische Wirtschaftsforschung, Discussion Paper No. 03-35, Mannheim.

Friedman, M. (1968). The Role of Monetary Policy. American Economic Review, Vol. 58 (1), 1-17.

Friedman M. (1977). Nobel Lecture: Inflation and Unemployment. Journal of Political Economy, Vol. 85(3), 451-472.

Galbraith, J. K. (1997). Time to Ditch the NAIRU. Journal of Economic Perspectives, Vol. 11(1), 93-108.

Galbraith, J.K., (1996). Inflation, Unemployment and the Job Structure. Jerome Levy Economics Institute, Working paper No. 154, 1-31.

Glyn, A. Baker, D. David, H. and Schmitt, J. (2004). Labor Market Institutions and Unemployment: A critical Assessment of the Cross-country Evidence, University of Oxford, Department of Economics Discussion Paper Series, No, 168.

Gordon, D.M (1988). The Un-Natural Rate of Unemployment: An Econometric Critique of the NAIRU Hypothesis. American Economic Review, Vol. 78(2), 117123.

Gordon, R.J., (1997). The Time-Varying NAIRU and Its Implications for Economic Policy. Journal of Economic Perspective. Vol. 11(1), 11-32.

Gordon, R.J. and Stock, J. H. (1998). Foundations of the Goldilocks Economy: Supply Shocks and the Time-Varying NAIRU. Brookings Papers on Economic Activity, Vol. 1998(2), 297-346.

Hall, R.E. (1975). The Rigidity of Wages and the Persistence of Unemployment. Brookings Papers on Economic Activity, Vol. 1975(2), 301-349.

Jekinson, T. (1987). The Natural Rate of Unemployment: Does it Exist? Oxford Review of Economic Policy, Vol. 3(3), 20-26.

Karanassou, M. and Snower, D.J. (1997). Is the Natural Rate a Reference Point? European Economic Review, Vol. 41(3-5), 559-569.

Layard, R. Nickell, S. and Jackman, R. (1991), Unemployment, Macroeconomic Performance and the Labor Market. Oxford University Press, Oxford. 
Lipsey, R.G. (1960). The Relation Between Unemployment and the Rate of Change of Money Wage Rates in the United Kingdom, 1862-1957: A Further Analysis. Economica, Vol. 27(105), 1-31.

Lucas, R.E. (1975). An Equilibrium Model of the Business Circle. Journal of Political Economy, Vol. 83(6), 1113-1144.

Lucas, R.E. (1973). Some International Evidence on Output-Inflation Trade-offs. American Economic Review, Vol. 63(3), pp. 326-334.

Lucas, R.E. (1972). Expectations and the Neutrality of Money, Journal of Economic Theory, Vol. 4(2), 103-124.

Mankiw, G.N. (2001). The Inexorable and Mysterious Trade-off between Inflation and Unemployment. Economic Journal, Vol. 111 (471), 45-61.

Mankiw, G.N. (1990). A Quick Refresher Course in Macroeconomics. Journal of Economic Literature, Vol. 28 (4), 1645-1660.

McCallum B.T. (1984). Monetarist Rules in the Light of Recent Experience. American Economic Review, Vol. 74(2), 388-391.

McDonald, I.M. (1995). Models of the Range Equilibria, in R. Cross (ed), The Natural Rate of Unemployment (101-152), Cambridge University Press, Cambridge.

Modigliani, F. and Papademos, L. (1975). Targets for Monetary Policy in the Coming Year. Brooking Papers on Economic Activity, Vol. 1975(1), 141-165.

Nickell, S. (1997). Unemployment and Labor Market Rigidities: Europe Versus North America. Journal of Economic Perspectives, Vol. 11(3), 55-74.

Nickell, S. (1998). Unemployment: Questions and Some Answers. Economic Journal, Vol. 108(448), 802-16.

Nickell, S. (1990). Unemployment: A Survey. Economic Journal, Vol. 100(401), 391439.

Phelps, E. (1968). Money-Wage Dynamics and Labor Market Dynamics. Journal of Political Economy, Vol. 78(4), 678-711.

Phelps, E. (1967). Phillips Curves, Expectations of Inflation and Optimal Unemployment over Time. Economica, Vol. 34(135), 254-281.

Phelps, E, and Zoera, G. (1998). Natural-Rate Theory and OECD Unemployment, Economic Journal, Vol. 108(448), 782-801.

Phillips, W.A. (1958). The Relationship between Unemployment and the Rate of Change of Money Wage Rates in the United Kingdom, 1861-1957. Economica, Vol. 25(100), 283-299. 
Rogerson, R. (1997). Theory Ahead of Language in the Economics of Unemployment. Journal of Economic Perspective, Vol. 11(1), 73-92.

Romer, D. (1993). The New Keynesian Synthesis. Journal of Economic Perspectives, Vol. 7 (1), 5-22.

Romer, C.D. and Romer, D.H. (1999). Monetary Policy and the Well Being of the Poor. Economic Review, Federal Reserve of Kansas City, Q1, 21-49, Kansas.

Samuelson, P.A. and Solow, R.M. (1960). Analytical Aspects of Anti-Inflation Policy. American Economic Review, Vol. 50 (2), 177-194.

Sargent, T.J. (1972). Anticipated Inflation and the Nominal Interest Rate. Quarterly Journal of Economics, Vol. 86(2), 212-225.

Sargent, T.J. Fand, D. and Goldfeld, S. (1973). Recent Expectations, the Real Rate of Interest, and the Natural Rate of Unemployment. Brookings Papers on Economic Activity, Vol. 1973(2), 429-480.

Sawyer, M.C. (2001). The NAIRU: A Critical Appraisal, in P. Arestis and M. Sawyer (eds), Money, Finance and Capitalist Development (220-254), Edward Elgar Publishing, Northampton Mass.

Sawyer, M.C. (1998). New Keynesian Macroeconomics and the Determination of Employment and Wages, in R. J. Rotherm (eds), New Keynesian Economics/Post Keynesian Alternatives, (118-133), Routledge, London.

Schreiber, S. and Wolters, J. (2007). The Long-Run Phillips Curve Revisited: Is the NAIRU Framework Data-Consistent? Journal of Macroeconomics, Vol. 29(2), 355-367.

Siebert, H. (1997). Labor Market Rigidities: At the Root of Unemployment in Europe. Journal of Economic Perspectives, Vol. 11(3), 37-54.

Solow, R.M. (1998). How Cautious Must the Fed Be?.in M. R. Solow and B. J. Taylor (eds), Inflation, Unemployment and Monetary Policy (1-28), MIT Press, Cambridge, MA.

Solow, R.M. (1986). Unemployment: Getting the Questions Right. Economica, Vol. 53(210), 23-34

Solow, R.M. (1979). Alternatively Approaches to Macroeconomic Theory: A Partial View. Canadian Journal of Economics, Vol. 12 (3), 339-354.

Snowdon, B. and Vane, H.R. (2005). Modern Macroeconomics: Its Origins, Development and Current State. Edward Elgar: Cheltenham, UK, Northampton, MA, USA.

Snowden, B. Vane, H. and Wynarczyk, P. (1994). A Modern Guide to Macroeconomics: An Introduction to Competing Schools of Thoughts. UK: Edward Elgar. 
Staiger, D. Stock, J. H. and Watson, M. W. (1997a). The NAIRU, Unemployment and Monetary Policy. The Journal of Economic Perspectives, Vol. 11(1), 33-49.

Staiger, D. Stock, J.H. and Watchon, M.W. (1997b). How Precise Are Estimates of the Natural Rate of Unemployment, in C. D. Romer and D. H Romer (eds), Reducing Inflation: Motivation and Strategy (195-246), NBER, University of Chicago Press, Chicago.

Stiglitz, J. (1997). Reflections on the Natural Rate Hypothesis. Journal of Economic Perspectives, Vol. 11 (1), 3-10.

Stock, J. H. and Watchon, M.W. (1999). Forecasting Inflation. Journal of Monetary Economics, Vol. 44(2), 293-335.

Stock, J.H. and Watchon, M.W. (1996). Evidence on Structural Instability in Macroeconomic Time Series Relations. Journal of Business and Economic Statistics, Vol. 14, 11-29.

Summers, L.H. Abraham, K.G. and Watchter, M.L. (1986). Why Is the Unemployment Rate So Very new Full Employment? Brookings Papers on Economic Activity, Vol. 1986(2), 339-396.

Taylor, J.B. (1999). A Historical Analysis of monetary Policy Rules, in J.B. Taylor (ed), Monetary Policy Rules (319-347), NBER- Business circles Series, Cambridge, MA.

Taylor, J.B. (1998). Monetary Policy Guideness for Employment and Inflation, in R .M. Solow and J.B. Taylor (eds), Inflation, Unemployment and Monetary Policy, MIT Press, Cambridge.

Taylor, J.B. (1995). The Monetary Transmission Mechanisms: An Empirical Framework, Journal of Economic Perspective, Vol. 9(4), 11-26.

Taylor, J.B. (1993). Discretion Versus Policy Rules in Practice. Carnegie- Rochester Conference Series on Public Policy, Vol. 39 (1993), 195-214.

Tobin, J. (1998). Monetary Policy: Recent Theory and Practice. Cowles Foundation Paper, No. 75.

Tobin, J. (1995). The Natural Rate as New Classical Macroeconomics, in R. Cross (ed.), The Natural Rate of Unemployment (32-42), Cambridge University Press, Cambridge.

Tobin, J. (1980). Stabilization Policy Ten Years After. Broking Papers on Economic Activity, Vol. 1980 (1), 19-89. 